\title{
Assessment of water contamination by potentially toxic elements in mangrove lagoons of the Red Sea, Saudi Arabia
}

\author{
Dhafer Ali Alamri • Samir G. Al-Solaimani - Refaat A. Abohassan • \\ Jörg Rinklebe (i) - Sabry M. Shaheen (i)
}

Received: 25 February 2021/Accepted: 20 April 2021/Published online: 26 May 2021

(C) The Author(s) 2021

\begin{abstract}
Mangrove (Avicennia marina) forests in the Red Sea cost have great concern from environmental, biological, economic, and social points of view. Therefore, assessing water contamination in this ecosystem is worth to be investigated. Consequently, here we aimed to examine the levels of salinity, acidity, and the total content of $\mathrm{Fe}, \mathrm{Mn}, \mathrm{Cu}, \mathrm{Zn}, \mathrm{Cd}, \mathrm{Cr}$, $\mathrm{Ni}$, and $\mathrm{Pb}$ in water samples collected from the upper, middle, and lower part of three mangrove lagoons (i.e., Al-Shuaiba, Yanbu, and Jeddah), Red Sea, Saudi
\end{abstract}

D. A. Alamri · S. G. Al-Solaimani ( $₫)$.

R. A. Abohassan · S. M. Shaheen $(\bowtie)$

Department of Arid Land Agriculture, Faculty of Meteorology, Environment, and Arid Land Agriculture,

King Abdulaziz University, Jeddah 21589, Saudi Arabia e-mail: salsolaimani@hotmail.com

S. M. Shaheen

e-mail: shaheen@uni-wuppertal.de

D. A. Alamri

e-mail: zaferta19@gmail.com

R. A. Abohassan

e-mail: rabuhasan@kau.edu.sa

J. Rinklebe · S. M. Shaheen

Laboratory of Soil and Groundwater-Management, School of Architecture and Civil Engineering, Institute of

Foundation Engineering, Water and Waste Management, University of Wuppertal, Pauluskirchstraße 7,

42285 Wuppertal, Germany

e-mail: rinklebe@uni-wuppertal.de
Arabia. The total metal content $\left(\mu \mathrm{g} \mathrm{L}^{-1}\right)$ in water samples differed significantly among the studied areas and ranged from 286.2 to 4815.0 for $\mathrm{Fe}, 86.4-483.0$ for $\mathrm{Mn}, 22.9-468.8$ for $\mathrm{Cu}, 199.2-366.6$ for $\mathrm{Zn}$, 44.1-99.8 for $\mathrm{Cd}, 25.6-80.3$ for $\mathrm{Cr}, 11.6-41.5$ for $\mathrm{Ni}$, and from 17.7 to 102.0 for $\mathrm{Pb}$. The mean values of $\mathrm{Cu}$, $\mathrm{Zn}, \mathrm{Cd}$, and $\mathrm{Pb}$ were higher than the $\mathrm{WHO}$ water quality standards for fisheries. Water samples in Yanbu were more contaminated and contained higher concentrations of all metals than Jeddah and Al-

\author{
J. Rinklebe \\ Department of Environment, Energy and Geoinformatics, \\ Sejong University, Seoul 05006, Republic of Korea \\ S. M. Shaheen \\ Department of Soil and Water Sciences, Faculty of \\ Agriculture, University of Kafrelsheikh, \\ Kafr El-Sheikh 33516, Egypt
}


Shuaiba, due to the petrochemical industries in this industrial area. Our findings suggest that the high metal content in the water of these mangrove sites, particularly in Yanbu, should be considered due to the high potential environmental and human health risks in these ecosystems. These results may help for demonstrating effective approaches for the management of these lagoons. More studies will be carried out on the sediment and mangrove plants in this ecosystem.

Keywords Water pollution - Heavy metals .

Mangrove forests · Risk assessment · Human and environmental health

\section{Introduction}

Contamination of aquatic environment by potentially toxic elements (PTEs) is a critical concern due to their potential toxicity and accumulation in aquatic habitats. Mangrove (Avicennia marina) lagoons have great concern from environmental, biological, economic, and social points of view (Constance et al., 2021; FAO, 2007; Leite et al., 2021; Long et al., 2021). The Mangrove lagoons in the Red Sea cost are productive but stressed by high temperature, high salinity, human activities, and potential pollution; therefore, they need continuous monitoring (Aljahdali \& Alhassan, 2020; Alzahrani et al., 2018; Rasul, 2015a, b; Sultan \& Ahmad, 1990). The anthropogenic activities and the utilization of the coasts may increase the level of pollutants including PTEs in these ecosystems (Albarakati \& Ahmad, 2019; Alzahrani et al., 2018; ImazLamadrid et al., 2019; Martínez-López et al., 2020).

Several studies have been carried out on PTEs pollution in water, sediments, and plants in mangrove environments worldwide (e.g., Bakshi et al., 2019; Bodin et al., 2013; Chi et al., 2019; Fernández-Cadena et al., 2014; He et al., 2014; Li et al., 2016). Specifically, some studies (e.g., El-Said \& Youssef, 2013; Usman et al., 2013; Alzahrani et al., 2018; Aljahdali and Alhassan, 2020) have been carried out on the mangrove lagoons in the red sea. However, those studies were mainly focused on the contamination of the sediments. Few studies (e.g., Hamed \& Emara, 2006) examined the level of PTEs in water samples; however, they examined the concentration of dissolved PTEs, and they did not study the total metal content in water. Consequently, the total PTE content in the water of mangrove lagoons is worth to be investigated.

Among the mangrove lagoons in the red sea in Saudi Arabia, examining the total PTE content in the water of the lagoon of the industrial city Yanbu and the lagoon of Jeddah (the biggest Red Sea coastal city in Saudi Arabia) is very urgent and critical because the first one (Yanbu) receives big amounts of industrial wastewater and the second one (Jeddah) receives huge amounts of sewage effluents as compared to some other lagoons like Al-Shuaiba. Consequently, here we aimed to examine the levels of salinity, acidity, and the total content of eight potentially toxic elements ( $\mathrm{Fe}$, $\mathrm{Mn}, \mathrm{Cu}, \mathrm{Zn}, \mathrm{Cd}, \mathrm{Cr}, \mathrm{Ni}$, and $\mathrm{Pb}$ ) in water samples collected from the upper, middle, and lower part of mangrove forest lagoons in Yanbu, Jeddah and AlShuaiba in the Red Sea coast, Saudi Arabia.

\section{Materials and methods}

\section{Studied areas}

The coastline of the Kingdom of Saudi Arabia is about $1,840 \mathrm{~km}$ in length, accounting for $79 \%$ of the eastern seaboard of the Red Sea (Badr et al., 2009; MEPA/ IUCN, 1987). There are over twenty elongated and shallow lagoons extending along the Saudi the Red Sea coast (Basaham et al., 2019; Rasul, 2015a, 2015b). In our study, we selected three lagoons, i.e., Jeddah, Yanbu, and Al-Shuaiba. Jeddah is one of the biggest Red Sea coastal Cities in Saudi Arabia. The studied site located at Corniche area and its $22 \mathrm{~km}$ south of Jeddah $\left(21.3207^{\circ} \mathrm{N}\right.$ and $21.3483^{\circ} \mathrm{N}$; Fig. 1). More details about this location are included in previous studies (e.g., El Sayed, 2002; Basaham et al., 2009). Al-Shuaiba lagoon $\left(14.3 \mathrm{~km}^{2} ; 20^{\circ} 46^{\prime} 2^{\prime \prime} \mathrm{N}\right.$ and $39^{\circ} 30^{\prime}$ $\left.21^{\prime \prime} \mathrm{E}\right)$ is located in the eastern coast of the Red Sea, Saudi Arabia (80 km south of Jeddah city) (Fig. 1). More details about this location are included in previous studies (e.g., Abohassan, 2013; Abu-Zied et al., 2011a, 2011b; Basaham et al., 2019). Yanbu is an industrial city on the eastern coast of Red Sea. The estimated area of Yanbu lagoon $\left(24^{\circ} 02^{\prime} 65^{\prime \prime} \mathrm{N}\right.$ and $38^{\circ}$ $09^{\prime} 46^{\prime \prime} \mathrm{E}$ ) is approximately $7500 \mathrm{~km}^{2}$. More details about this location are included in previous studies 
(e.g., Al-Barakati, 2012; Abohassan, 2013; Alharbi et al,. 2019).

Sampling, characterization, and metal content

In each site, four transects have been set in the northsouth orientation. Three water samples were randomly collected from three different points at the beginning (upper; site 1), middle (site 2), and end (lower; site 3) of transect (Fig. 1). Water samples (about 2L) were collected and tightly sealed in polyethylene bottles and transferred to the laboratory. Water salinity and $\mathrm{pH}$ were measured using EC- and $\mathrm{pH}$-meter. A part of the water samples was acidified by nitric acid $\left(\mathrm{HNO}_{3}\right)$ for elemental analyses. Fifty milliliters of each acidified water sample was digested with a mixture of concentrated nitric acid $\left(\mathrm{HNO}_{3} ; 5 \mathrm{ml}\right)$ and perchloric acid $\left(\mathrm{CHIO}_{4} ; 2 \mathrm{ml}\right)$ for analyses of the total metal content in the water.

The mixture of water and acids was left overnight and then heated in the next day, and the temperature was gradually increased from 100 to $225^{\circ} \mathrm{C}$ over a period of $6 \mathrm{~h}$ until full digestion. Distilled water was then added into each tube containing sample solution up to $50 \mathrm{ml}$ and filtered through acid-resistant filter paper, as described in the standard methods for the examination of water and wastewater (APHA, 2005) and used also by Kopp and Korner (1967) and Shaheen and Tsadilas (2009). The total metals were measured using graphite furnace-atomic absorption spectrophotometer (Shimadzu AA7000).

Quality assurance, statistical analyses, and creating figure

The used glasswares were water and/or acid cleaned, and the used chemicals were analytical reagent grade. The water salinity, acidity, and metal content were analyzed in triplicates using calibrated equipments with acceptable uncertainties. The laboratory usually applies an internal quality assurance system. During metal analyses, different concentration levels (e.g., 1000, 100, 50, 25, and $12.5 \mu \mathrm{g} \mathrm{L}^{-1}$ ) were measured as an internal quality control. The RSD values were less than $5 \%$. The limits of detection (LOD) obtained for $\mathrm{Cu}, \mathrm{Fe}, \mathrm{Mn}, \mathrm{Pb}$, and $\mathrm{Zn}$ were 5.4, 6.2, 1.4, 12.0, and 1.8 $\mu \mathrm{L}^{-1}$, respectively.

Descriptive statistics were performed using the SPSS 22 software (SPSS, Chicago, IL, USA). All

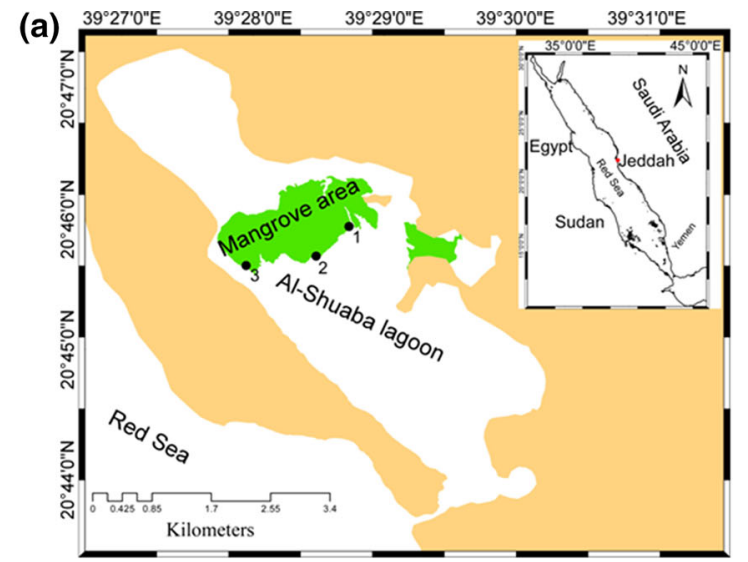

(b)
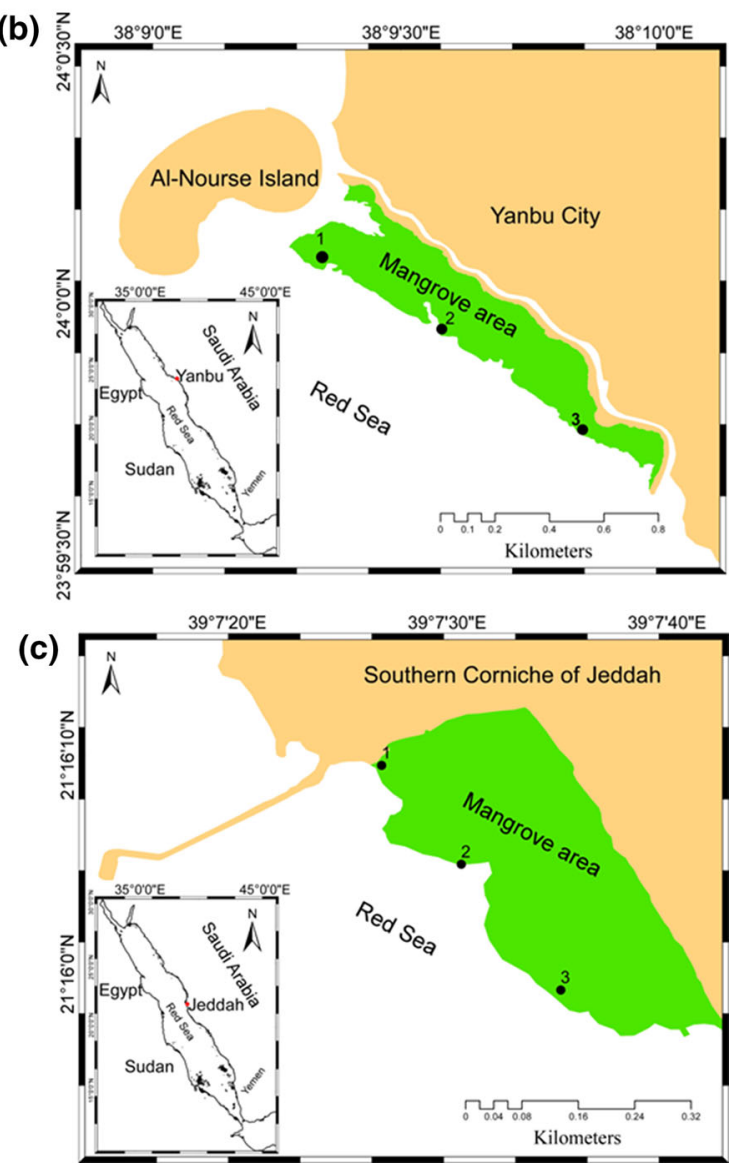

Fig. 1 Maps of the studied locations: a Al-Shuaiba, b Yanbu, and $\mathbf{c}$ Jeddah

results were analyzed statistically using one-way ANOVA to compare the means of different between the systems. The individual means were compared by Duncan's test to a level of 5\% using SPSS version 22. 
OriginPro 9.1 b215 (OriginLab Corporation, Northampton, USA) was used to create the figures.

\section{Results and discussions}

Water salinity and $\mathrm{pH}$

The studied water samples in the three lagoons were salty with electrical conductivity $(\mathrm{EC} ; \mathrm{dS} / \mathrm{m})$ values differed significantly among the sites and varied from 53.8 in Jeddah to 69.4 in Al-Shuaiba (Table 1). The average EC values were $54.2 \mathrm{dS} / \mathrm{m}, 58.5 \mathrm{dS} / \mathrm{m}$, and $68.2 \mathrm{dS} / \mathrm{m}$ in Jeddah, Yanbu, and Al-Shuaiba, respectively (Table 1). Among the different sampling points (upper, middle, and lower) in each site, the water salinity of the middle part of Al-Shuaiba lagoon was significantly higher than the upper and lower part (Fig. 2a), while there were no significant variations between the points in Yanbu and Jeddah lagoons (Fig. 2a). In general, the high water salinity in the three sites of the Red Sea might be explained by the high temperature (tropical-subtropical climate) and high evaporation and low precipitation. Also, there is no dilution for this high saline sea water with Rivers water because the Red Sea is a semi-enclosed, marginal basin and having micro-tidal conditions, and thus, no rivers or streams are connected with the Red Sea and its lower connection to the Gulf of Aden is narrow (Abu-Zied \& Bantan, 2013; Morcos, 1970). Among the three lagoons, Al-Shuaiba water showed the highest salinity (Fig. 2). Al-Shuaiba Lagoon is a sheltered, fossil back-reef, hyper-saline water body (Abu-Zied \& Bantan, 2013; Abu-Zied et al., 2011a, 2011b). The relatively lower salinity in Jeddah lagoon water can be explained by dilution the saline water with wastewater from the urbanized surrounding area.

The $\mathrm{pH}$ of the studied water samples in the three lagoons varied from 6.84 in Jeddah to 7.56 in Yanbu (Table 1). The average $\mathrm{pH}$ values were 7.4, 7.2, and 6.8 in Yanbu, Jeddah, and Al-Shuaiba, respectively (Table 1). Among the different sampling points (upper, middle, and lower) in each site, the water $\mathrm{pH}$ of the middle part of Al-Shuaiba lagoon was significantly higher than the upper and lower part (Fig. 2b), while there were no significant variations between the points in Yanbu and Jeddah lagoons (Fig. 2b). The higher $\mathrm{pH}$ in Yanbu lagoon water than the other lagoons might be due to the discharge of alkaline industrial wastewater into the lagoons (Alharbi et al., 2019).

\section{Total metal content in water}

The total metal content in the water samples varied widely among the sites and metals (Fig. 4). Among the studied metals, Fe showed the highest average values in the three lagoons (Fig. 3), followed by $\mathrm{Zn}, \mathrm{Cu}, \mathrm{Mn}$, $\mathrm{Cr}, \mathrm{Cd}, \mathrm{Pb}$, and $\mathrm{Ni}$ in $\mathrm{Al}-$ Shuaiba lagoon, by $\mathrm{Zn}, \mathrm{Cu}$, $\mathrm{Mn}, \mathrm{Cd}, \mathrm{Pb}, \mathrm{Cr}$, and $\mathrm{Ni}$ in Yanbu Lagoon, and followed by $\mathrm{Cu}, \mathrm{Zn}, \mathrm{Mn}, \mathrm{Cd}, \mathrm{Pb}, \mathrm{Cr}$, and $\mathrm{Ni}$ in Jeddah Lagoon (Fig. 3). The higher Fe content in the water than $\mathrm{Zn}, \mathrm{Cu}, \mathrm{Mn}, \mathrm{Cd}, \mathrm{Pb}, \mathrm{Ni}$, and $\mathrm{Cr}$ can be due to either geogenic or anthropogenic sources. The geogenic inputs might be due to the enrichments of the lagoon sediments by $\mathrm{Fe}$-(oxyhydr)oxides, which can be reductively dissoluted under the flooding conditions, and therefore, Fe as well as the other bounded/ occluded meals can be released to the water (Shaheen et al., 2014, 2020). Also, the suspended colloidal particles in the water bodies of the lagoons can be rich in the Fe-(oxyhydr)oxides, which increase the particulate and total content of $\mathrm{Fe}$ in the water (Shaheen et al., 2013; Cusack et al., 2020). The enrichment of red sea sediments by total $\mathrm{Fe}$ has been reported in some studies (e.g., Basaham et al., 2009; Aljahdali and Alhassan, 2020). The anthropogenic sources for $\mathrm{Fe}$ and heavy metals can be due to the discharge of industrial, municipal, and sewage wastewater into the lagoons as reported in other studies (e.g., El Sayed, 2002; Basaham et al., 2009; Alharbi et al., 2019; Cusack et al., 2020) and as it will be discussed below.

The concentrations $\left(\mu \mathrm{g} \mathrm{L}^{-1}\right)$ of total Fe in the water samples differed between the three lagoons and varied from 286.2 in Al-Shuaiba to 4815.0 in Yanbu (Table 1). The variations between the average concentrations of $\mathrm{Fe}\left(568.8-2367.2 \mu \mathrm{g} \mathrm{L}^{-1}\right)$ in the three lagoons differed significantly (Fig. 3). Also, the variations between the average concentrations of $\mathrm{Fe}$ in the upper, middle, and lower part of each lagoon differed significantly in Yanbu and Jeddah lagoons, but were nonsignificant in Al-Shuaiba lagoon (Fig. 4).

The concentrations $\left(\mu \mathrm{g} \mathrm{L}^{-1}\right.$ ) of total $\mathrm{Mn}$ in the water samples differed between the three lagoons and varied from 86.4 in Al-Shuaiba to 483.3 in Yanbu lagoon (Table 1). The average concentrations of $\mathrm{Mn}$ $\left(264.8 \mu \mathrm{g} \mathrm{L}^{-1}\right)$ in Yanbu water were significantly 
Table 1 Variations of EC, $\mathrm{pH}$, and metal concentrations in the water samples $(n=9)$ of the studied lagoons

$E C$ Electrical conductivity

\begin{tabular}{|c|c|c|c|c|c|}
\hline Parameter & Unit & Minimum & Maximum & Mean & Standard deviation \\
\hline \multicolumn{6}{|c|}{ Al-Shuaiba lagoon } \\
\hline $\mathrm{EC}$ & $\mathrm{dS} \mathrm{m} \mathrm{m}^{-1}$ & 60.70 & 69.40 & 64.43 & 3.39 \\
\hline $\mathrm{pH}$ & - & 6.99 & 7.21 & 7.09 & 0.08 \\
\hline $\mathrm{Fe}$ & {$\left[\mu \mathrm{g} \mathrm{L}^{-1}\right]$} & 286.2 & 822.0 & 568.8 & 142.4 \\
\hline $\mathrm{Mn}$ & & 86.4 & 170.4 & 115.9 & 24.2 \\
\hline $\mathrm{Cu}$ & & 22.9 & 234.9 & 117.4 & 55.8 \\
\hline $\mathrm{Zn}$ & & 199.2 & 241.6 & 220.8 & 14.0 \\
\hline $\mathrm{Cd}$ & & 44.1 & 52.6 & 46.7 & 3.1 \\
\hline $\mathrm{Cr}$ & & 45.7 & 71.5 & 56.3 & 9.0 \\
\hline $\mathrm{Ni}$ & & 11.6 & 20.9 & 15.2 & 3.3 \\
\hline $\mathrm{Pb}$ & & 17.7 & 42.0 & 31.4 & 6.9 \\
\hline \multicolumn{6}{|c|}{ Yanbu lagoon } \\
\hline $\mathrm{EC}$ & $\mathrm{dS} \mathrm{m}^{-1}$ & 57.60 & 59.00 & 58.50 & 0.40 \\
\hline $\mathrm{pH}$ & - & 7.14 & 7.56 & 7.41 & 0.14 \\
\hline $\mathrm{Fe}$ & {$\left[\mu \mathrm{g} \mathrm{L}^{-1}\right]$} & 1321.5 & 4815.0 & 2367.2 & 1199.1 \\
\hline $\mathrm{Mn}$ & & 186.0 & 483.0 & 264.8 & 86.7 \\
\hline $\mathrm{Cu}$ & & 243.8 & 445.1 & 376.0 & 71.7 \\
\hline $\mathrm{Zn}$ & & 331.5 & 366.6 & 347.2 & 13.4 \\
\hline $\mathrm{Cd}$ & & 82.9 & 99.8 & 92.2 & 6.5 \\
\hline $\mathrm{Cr}$ & & 49.6 & 80.3 & 68.2 & 12.2 \\
\hline $\mathrm{Ni}$ & & 19.1 & 41.5 & 32.5 & 6.5 \\
\hline $\mathrm{Pb}$ & & 36.8 & 102.0 & 69.9 & 19.7 \\
\hline \multicolumn{6}{|c|}{ Jeddah Lagoon } \\
\hline $\mathrm{EC}$ & $\mathrm{dS} \mathrm{m} \mathrm{m}^{-1}$ & 53.80 & 54.50 & 54.20 & 0.23 \\
\hline $\mathrm{pH}$ & - & 6.84 & 7.46 & 7.21 & 0.18 \\
\hline $\mathrm{Fe}$ & {$\left[\mu \mathrm{g} \mathrm{L}^{-1}\right]$} & 938.6 & 1872.0 & 1452.2 & 285.3 \\
\hline $\mathrm{Mn}$ & & 133.2 & 222.0 & 184.4 & 30.1 \\
\hline $\mathrm{Cu}$ & & 76.5 & 468.8 & 240.9 & 119.0 \\
\hline $\mathrm{Zn}$ & & 241.0 & 286.0 & 267.4 & 12.2 \\
\hline $\mathrm{Cd}$ & & 56.5 & 85.8 & 72.0 & 9.7 \\
\hline $\mathrm{Cr}$ & & 25.6 & 59.5 & 40.7 & 11.6 \\
\hline $\mathrm{Ni}$ & & 18.6 & 26.7 & 23.4 & 2.5 \\
\hline $\mathrm{Pb}$ & & 19.2 & 70.6 & 50.9 & 17.8 \\
\hline
\end{tabular}

higher than Jeddah and Al-Shuaiba water (Fig. 3). Although the upper part showed significantly higher concentrations of Mn than the middle and lower part of Al-Shuaiba lagoon, the lower part showed significantly higher concentrations than the upper and middle part of Yanbu lagoon, while the middle part showed significantly higher concentrations than the upper and lower part of Jeddah lagoon (Fig. 4).

The total content $\left(\mu \mathrm{g} \mathrm{L}^{-1}\right)$ of total $\mathrm{Cu}$ ranged between 22.9 in Al-Shuaiba and 468.8 in Jeddah (Table 1). The average concentrations of $\mathrm{Cu}(376.0 \mu \mathrm{g}$
$\mathrm{L}^{-1}$ ) in Yanbu water was significantly higher than Jeddah (240.9 $\left.\mu \mathrm{g} \mathrm{L}^{-1}\right)$ and Al-Shuaiba water (117.4; Fig. 3). The upper part was more contaminated by $\mathrm{Cu}$ than the middle and lower part of Yanbu and Jeddah lagoons, while the lower part showed significantly higher $\mathrm{Cu}$ concentrations than the upper and middle part of Al-Shuaiba lagoon; however, the variations between $\mathrm{Cu}$ concentrations in the upper, middle, and lower parts of the lagoons were nonsignificant (Fig. 4). 

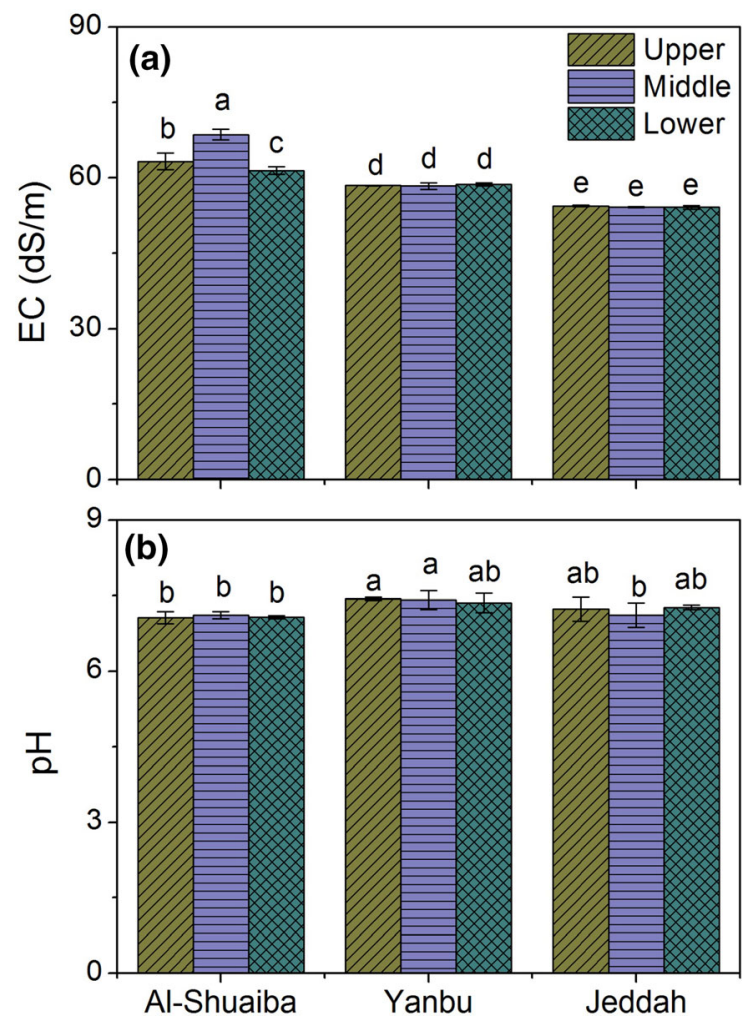

Fig. 2 Average values of electrical conductivity and $\mathrm{pH}$ in the water samples of the upper, middle, and lower part of the studied lagoons. Values accompanied by different letters are significantly different within columns at the level $(P<0.05)$

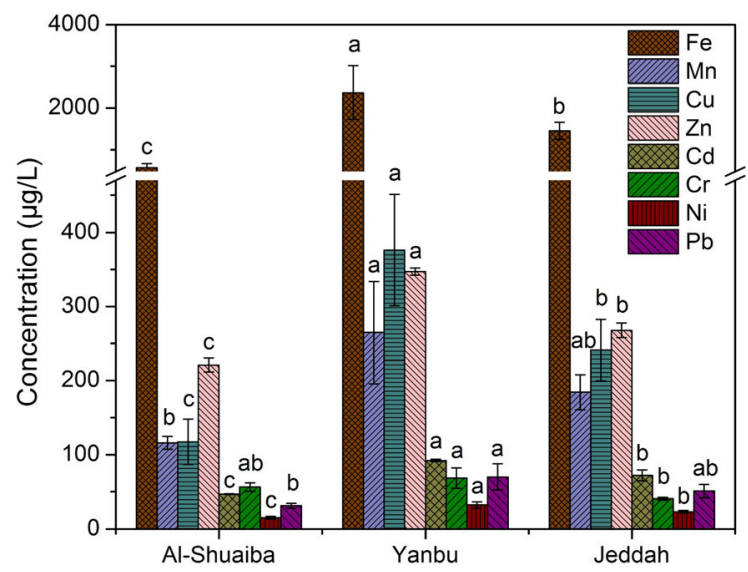

Fig. 3 Average values of the total content of $\mathrm{Fe}, \mathrm{Mn}, \mathrm{Cu}, \mathrm{Zn}$, $\mathrm{Cd}, \mathrm{Cr}, \mathrm{Ni}$, and $\mathrm{Pb}$ in the water samples of the studied lagoons. Each metal values accompanied by different letters are significantly different within lagoons at the level $(P<0.05)$

The total content $\left(\mu \mathrm{g} \mathrm{L}^{-1}\right)$ of $\mathrm{Zn}$ ranged between 199.2 in Al-Shuaiba and 366.6 in Yanbu (Table 1).
The average concentration of total $\mathrm{Zn}$ in Yanbu water (347.2 $\mu \mathrm{g} \mathrm{L}^{-1}$ ) was significantly higher than Jeddah (267.4 $\left.\mu \mathrm{g} \mathrm{L}^{-1}\right)$ and Al-Shuaiba water $\left(220.8 \mu \mathrm{g} \mathrm{L}^{-1}\right)$ (Fig. 3). The variations between total $\mathrm{Zn}$ content in the lower, upper, and middle parts were nonsignificant in the three lagoons (Fig. 4).

The concentrations of total $\mathrm{Cd}$ in the water samples varied from $44.1 \mu \mathrm{g} \mathrm{L}^{-1}$ in Al-Shuaiba lagoon to $99.8 \mu \mathrm{g} \mathrm{L}^{-1}$ in Yanbu lagoon (Table 1). The average concentrations of total $\mathrm{Cd}$ in Yanbu water $(92.2 \mu \mathrm{g}$ $\left.\mathrm{L}^{-1}\right)$ were significantly higher than Jeddah $(72.0 \mu \mathrm{g}$ $\mathrm{L}^{-1}$ ) and Al-Shuaiba water $\left(46.7 \mu \mathrm{g} \mathrm{L}^{-1}\right)$ (Fig. 3). The variations of total $\mathrm{Cd}$ content among the upper, middle, and lower parts of the lagoons differed significantly in Jeddah lagoon, but were nonsignificant in Al-Shuaiba and Yanbu lagoons (Fig. 4).

The total content $\left(\mu \mathrm{g} \mathrm{L}^{-1}\right)$ of total $\mathrm{Cr}$ ranged between 25.6 in Jeddah and 80.3 in Yanbu lagoon (Table 1). The average values of total $\mathrm{Cr}$ content in Yanbu water $\left(68.2 \mu \mathrm{g} \mathrm{L}^{-1}\right)$ and Al-Shuaiba water (56.3) were significantly higher than Jeddah water (40.7) (Fig. 3). The variation between $\mathrm{Cr}$ average concentrations in the upper, middle, and lower part of the lagoons was significant in Yanbu water, while it was nonsignificant Al-Shuaiba and Jeddah lagoons (Fig. 4).

The concentrations $\left(\mu \mathrm{g} \mathrm{L}^{-1}\right)$ of total $\mathrm{Ni}$ in the water samples varied from 11.6 in Al-Shuaiba to 41.5 in Yanbu lagoon (Table 1). The average concentrations of total Ni in Yanbu water $\left(32.5 \mu \mathrm{g} \mathrm{L}^{-1}\right)$ and Jeddah water $\left(23.4 \mu \mathrm{g} \mathrm{L}^{-1}\right)$ were significantly higher than AlShuaiba water $\left(15.2 \mu \mathrm{g} \mathrm{L}^{-1}\right)$ (Fig. 3). The variation of total $\mathrm{Ni}$ content among the upper, middle, and lower parts differed significantly in Yanbu lagoon, while it was nonsignificant in Al-Shuaiba and Jeddah lagoons (Fig. 4).

The total content $\left(\mu \mathrm{g} \mathrm{L}^{-1}\right)$ of $\mathrm{Pb}$ in the water samples ranged between 17.7 in Al-Shuaiba lagoon and 102.0 in Yanbu lagoon (Table 1). The mean values of total $\mathrm{Pb}$ in were $69.9 \mu \mathrm{g} \mathrm{L}^{-1}$ in Yanbu water, $50.9 \mu \mathrm{g} \mathrm{L}^{-1}$ in Jeddah water, and $31.4 \mu \mathrm{g} \mathrm{L}^{-1}$ in AlShuaiba water (Fig. 3). The mean value in Yanbu lagoon water was significantly higher Al-Shuaiba and Jeddah lagoons (Fig. 3). The water of the middle part in Al-Shuaiba and Yanbu lagoons contains higher $\mathrm{Pb}$ than the upper and lower part, while the water of the lower part in Jeddah lagoon contains higher $\mathrm{Pb}$ than the upper and middle part; however, the variations 

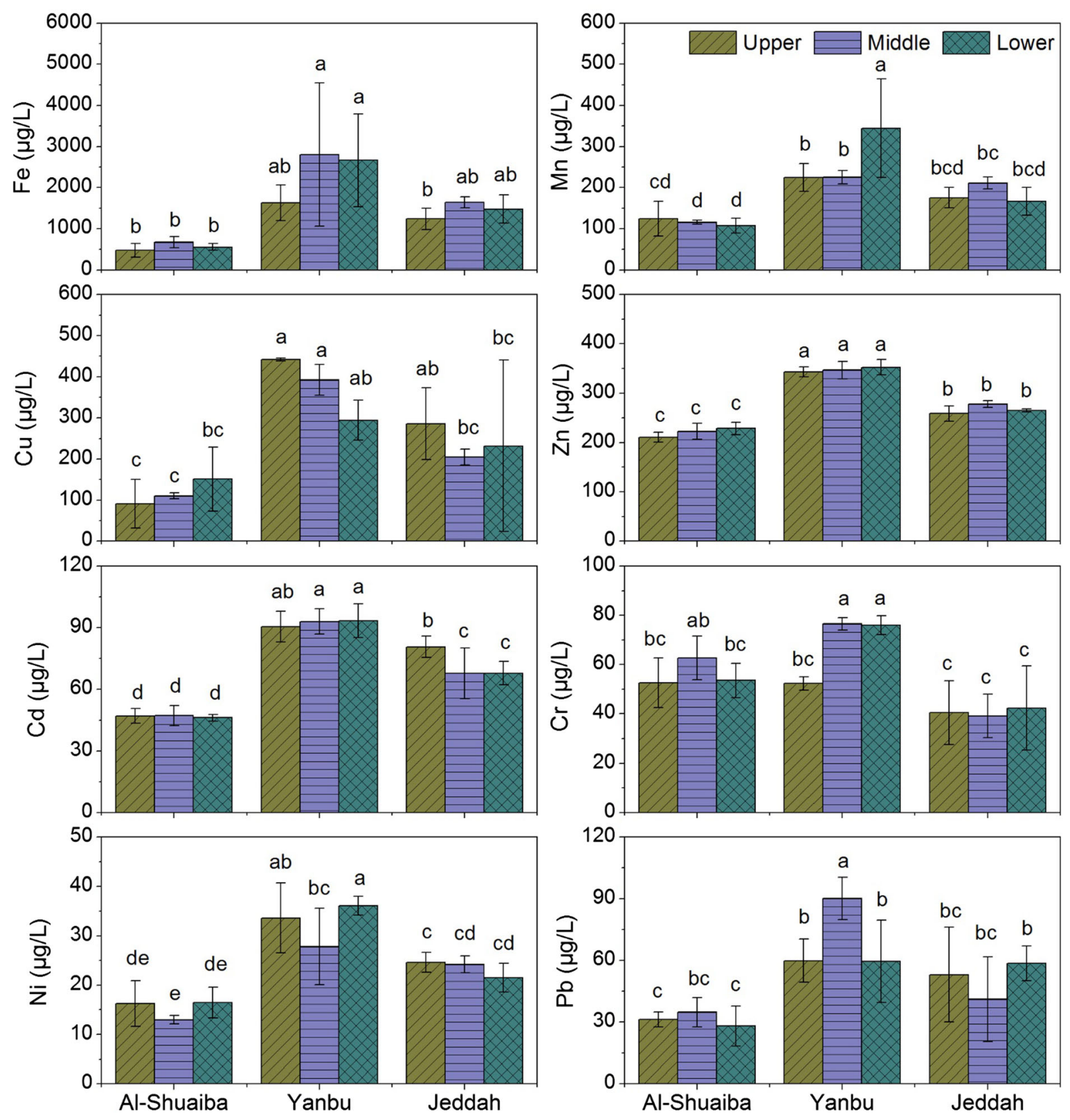

Fig. 4 Average values of the total content of $\mathrm{Fe}, \mathrm{Mn}, \mathrm{Cu}, \mathrm{Zn}$, $\mathrm{Cd}, \mathrm{Cr}, \mathrm{Ni}$, and $\mathrm{Pb}$ in the water samples of the upper, middle, and lower part of the studied lagoons of the studied lagoons. Each

between total $\mathrm{Pb}$ content in the parts were significant only in Yanbu lagoon (Fig. 4).

The metal values were within the global range of metal content in surface water bodies as reviewed and reported by Kumar et al. 2019 (Table 2). The mean values of $\mathrm{Fe}, \mathrm{Mn}, \mathrm{Cu}, \mathrm{Zn}, \mathrm{Cd}$, and $\mathrm{Ni}$ were lower than

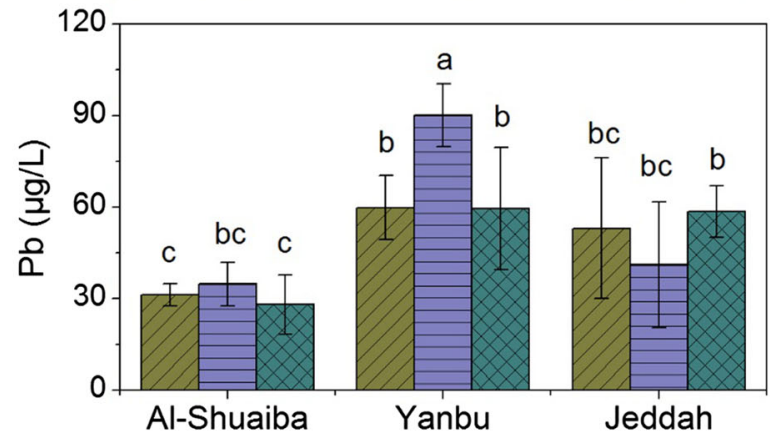

metal values accompanied by different letters are significantly different within parts and lagoons at the level $(P<0.05)$

the highest permitted value for drinking water according to the world health organization, while the mean values of $\mathrm{Cr}$ and $\mathrm{Pb}$ was higher than those limits (Table 2) (WHO, 2017). The mean values of Mn, Cd, $\mathrm{Ni}$, and $\mathrm{Pb}$ were higher than the highest permitted value for drinking water according to the US 


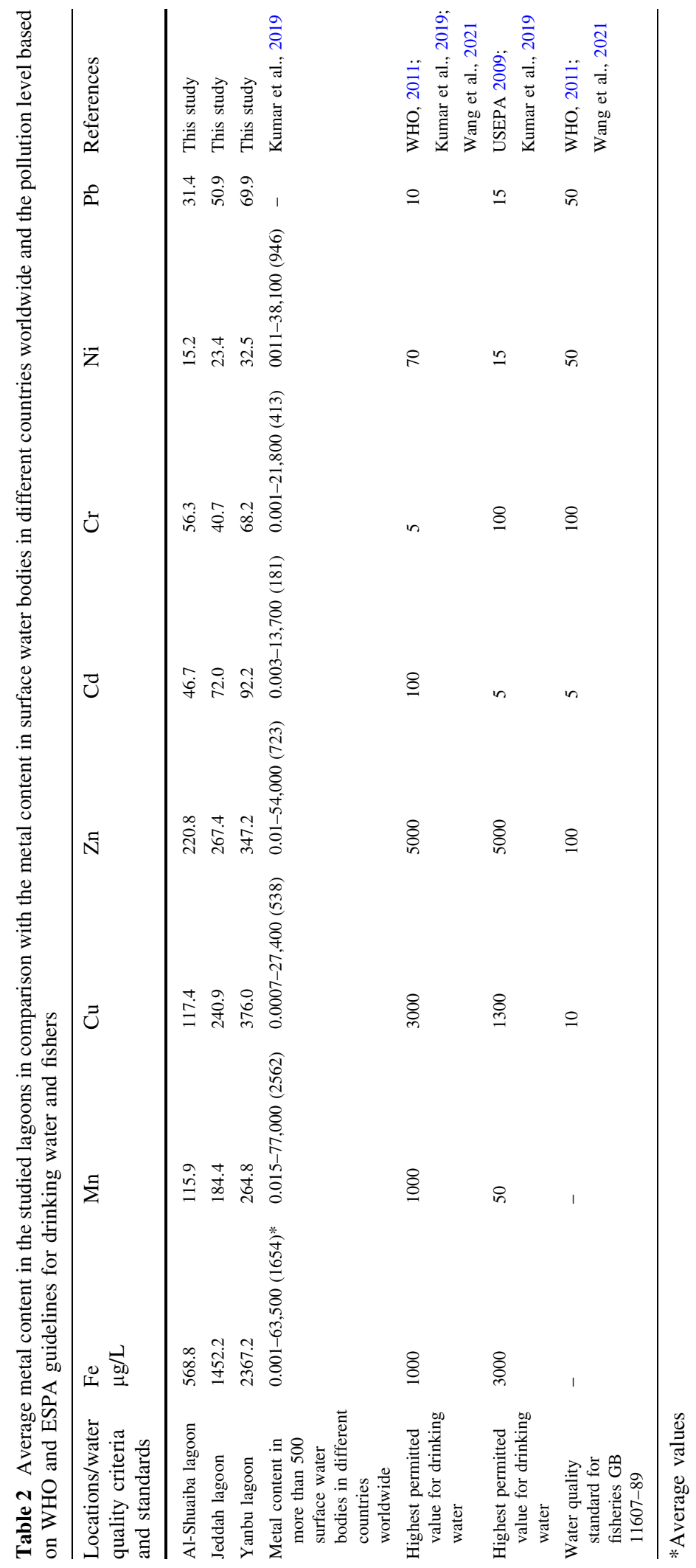


Environmental Protection Agency (USEPA), while the mean values of $\mathrm{Fe}, \mathrm{Cu}, \mathrm{Cr}$, and $\mathrm{Zn}$ was lower than those limits (Table 2) (USEPA, 2009). Also, the mean values of $\mathrm{Cu}, \mathrm{Zn}, \mathrm{Cd}$, and $\mathrm{Pb}$ were higher than the water quality standards for fisheries according to the WHO (Wang et al., 2021; WHO, 2011). The high concentrations of these metals in the water samples of the studied lagoons may pose a great threat to these ecosystems.

The water samples in Yanbu site were more contaminated and contained higher concentrations of all metals than Jeddah and Al-Shuaiba. The high contamination in the water of Yanbu might be due to the petrochemical industries in this industrial area. Yanbu is an industrial city and contains the industrial harbor, the largest oil transport harbor, oil refineries, petrochemical factories, cement factories, desalination plants, and power generation plants (Al-Barakati, 2012; Abohassan, 2013; Alharbi et al., 2019). Therefore, these different industries can be a source of these toxic elements and a reason for increasing the levels of these elements in the water samples of this site.

The high metal content in the water of Jeddah can be explained by the discharge of sewage water in this touristic area. Twenty one years ago, primary sewagetreated wastewater has been dumped into semienclosed coastal lagoon $\left(2.5 \mathrm{~km}^{2}\right)$ into the coastal water south of Jeddah (Southern Corniche). The sewage effluent rich in organic and metallic pollutants was retained within the lagoon (El Sayed, 2002; Basaham et al., 2009). Therefore, these sewage effluents can be a source of toxic elements in the water samples of Jeddah site. Also, the human activities in these areas such as transportation, construction, and manufacturing can produce large quantities of waste materials that cause water pollution (Bodin et al., 2013; Marchand et al., 2006; Alzahrani et al., 2018).

The higher metal content in the water samples of the upper part than the other parts might be due to its location close to the industrial and domestic pollution source, as also reported by Hamed and Emara (2006) in the northwestern part of Red Sea (Gulf of Suez).

\section{Conclusions}

Contamination of mangrove forests in the Red Sea coast by potentially toxic elements can lead to adverse environmental, biological, economic, and social impacts on these ecosystems. Also, the high environmental stress in the arid zone mangrove lagoons due to high temperature, salinities, and high PTEs content can affect the plants, fish, and human health. Therefore, in our study we selected three mangrove forest lagoons (i.e., Al-Shuaiba, Yanbu, and Jeddah) in the Red Sea coast in Saudi Arabia and examined the levels of salinity, acidity, and the total content of $\mathrm{Fe}, \mathrm{Mn}, \mathrm{Cu}$, $\mathrm{Zn}, \mathrm{Cd}, \mathrm{Cr}, \mathrm{Ni}$, and $\mathrm{Pb}$ in water. Based on our results, we can conclude that these lagoons, particularly AlShuaiba, suffer from highly salinity $(69.4 \mathrm{dS} / \mathrm{m})$. Also, these lagoons, particularly Yanbu and Jeddah contained high concentrations of total PTEs and the levels of these PTEs exceeded the standard limits of these two metals in the wastewater as reported by WHO and USEPA. The high concentrations of these metals in the water samples of the studied lagoons, particularly the upper part of Yanbu and Jeddah, may pose a great threat to these ecosystems. The mangrove ecosystems in the studied lagoons are highly affected by anthropogenic activities including urbanization, petrochemical industries, desalination and power generation plants, and wastewater treatment plants. For examples, the higher metal content in Yanbu site is mainly due to the petrochemical industries in this industrial area, while the high metal content in the water of Jeddah is likely due to the discharge of sewage water.

Our findings suggest that the high metal content in the water of these mangrove sites, particularly in Yanbu, should be considered due to the increase the potential environmental and human health risks in these ecosystems. These results may enable a more accurate prediction of water pollution in these mangrove forests in response to changing environmental, industrial, and social conditions. Moreover, this may help stakeholders and policy makers for creating new business opportunities for fish and wood producers and also for demonstrating sustainable and effective approaches for the management of these ecosystems.

More studies will be carried out to assess the content of these metals in sediment and different organs of mangrove plants and also to assess the pollution level in this ecosystem and the potentiality of mangrove plants for phytoremediation.

Acknowledgements This work is a part of the Master theses of the first author. Technical assistances from the Laboratory of Soil Sciences at the Department of Arid Land Agriculture, 
Faculty of Meteorology, Environment, and Arid Land Agriculture, King Abdulaziz University, are acknowledged.

Author contribution DAA carried out investigations, sampling, analyses, and writing the original draft. SGA was involved in supervision and foundation. RAA took part in software and visualization. JR had contributed to review and editing. SMS performed supervision, review, and editing.

Funding Open Access funding enabled and organized by Projekt DEAL. No funding was received to assist with the preparation of this manuscript.

\section{Declaration}

Conflict of interest The authors declare that they have no known competing financial interests or personal relationships that could have appeared to influence the work reported in this paper.

Consent for publication The authors are responsible for correctness of the statements provided in the manuscript. The publication has been approved by all co-authors. The publication has been approved by all co-authors.

Consent to participate Informed consent was obtained from all individual participants included in the study.

Open Access This article is licensed under a Creative Commons Attribution 4.0 International License, which permits use, sharing, adaptation, distribution and reproduction in any medium or format, as long as you give appropriate credit to the original author(s) and the source, provide a link to the Creative Commons licence, and indicate if changes were made. The images or other third party material in this article are included in the article's Creative Commons licence, unless indicated otherwise in a credit line to the material. If material is not included in the article's Creative Commons licence and your intended use is not permitted by statutory regulation or exceeds the permitted use, you will need to obtain permission directly from the copyright holder. To view a copy of this licence, visit http://creativecommons.org/licenses/by/4.0/.

\section{References}

Abohassan, R.A., (2013) Heavy metal pollution in avicennia marina mangrove systems on the Red Sea Coast of Saudi Arabia. JKAU: Meteorology, Environment and Arid Land Agriculture Sciences 24(1):35-53.

Abu-Zied, R. H., \& Bantan, R. A. (2013). Hypersaline benthic foraminifera from the Shuaiba Lagoon, eastern Red Sea, Saudi Arabia: Their environmental controls and usefulness in sea-level reconstruction. Marine Micropaleontology, $103,51-67$

Abu-Zied, R. H., Bantan, R. A., \& El Mamoney, M. H. (2011). Present environmental status of the Shuaiba Lagoon, Red Sea Coast, Saudi Arabia. Journal of King Abdulaziz. University Marine Sciences, 22(2), 159-179
Abu-Zied, R. H., Bantan, R. A., \& El Mamoney, M. H. (2011). Present environmental status of the Shuaiba Lagoon, Red Sea Coast Saudi Arabia. JKAU: Marine Science, 22(2), 159-179

Albarakati A.M.A., Ahmad F., (2019).Red Sea Coastal Lagoons: Their dynamics and future challenges. In: Rasul N., Stewart I. (Ed.) Oceanographic and biological aspects of the Red Sea. Springer Oceanography. Springer, https:// doi.org/10.1007/978-3-319-99417-8_7.

Alharbi, O. M. L., Khattab, R. A., Ali, I., et al. (2019). Assessment of heavy metals contamination in the sediments and mangroves (Avicennia marina) at Yanbu coast, Red Sea, Saudi Arabia. Marine Pollution Bulletin, 149, 110669. https://doi.org/10.1016/j.marpolbul.2019.110669.

Aljahdali, M. O., \& Alhassan, A. B. (2020). Ecological risk assessment of heavy metal contamination in mangrove habitats, using biochemical markers and pollution indices: A case study of Avicennia marina L. in the Rabigh lagoon, Red Sea. Saudi Journal of Biological Sciences, 27, 1174-1184

Alzahrani, D. A., El-Metwally, M., Selim, M., \& M., El-Sherbiny. . (2018). Ecological assessment of heavy metals in the grey mangrove (Avicennia marina) and associated sediments along the Red Sea coast of Saudi Arabia. Oceanologia, 60, 513-526

APHA (2005) Standard methods for the examination of water and wastewater. In: 21st (Ed.) American public health association.

Badr, N. B. E., El-Fiky, A. A., Mostafa, A. R., et al. (2009). Metal pollution records in core sediments of some Red Sea coastal areas, Kingdom of Saudi Arabia. Environmental Monitoring and Assessment, 155, 509-526

Bakshi, M., Ghosh, S., Ram, S., Sudarshan, M., Chakraborty, A., Biswas, J. K., Shaheen, S. M., Niazi, N. K., Rinklebe, J., \& Chaudhuri, P. (2019). Sediment quality, elemental bioaccumulation and antimicrobial properties of mangroves of Indian Sundarban. Environmental Geochemistry and Health, 41(1), 275-296

Basaham, A. S., Rifaat, A. E., El-Mamoney, M. H., \& El Sayed, M. A. (2009). Re-evaluation of the impact of sewage disposal on coastal sediments of the Southern Corniche. Jeddah, Saudi Arabia Journal of King Abdulaziz University-Marine Sciences, 20, 109-126

Basaham, A. S., El Sayed, M. A., Ghandour, I. M., \& Masuda, H. (2015). Geochemical background for the Saudi Red Sea coastal systems and its implication for future environmental monitoring and assessment. Environment and Earth Science, 74, 4561-4570

Basaham, A. S., Ghandour, I. M., \& Haredy, R. (2019). Controlling factors on the geochemistry of Al-Shuaiba and AlMejarma coastal lagoons, Red Sea, Saudi Arabia. Open Geoscience, 11, 426-439

Bodin, N., N'Gom-Kâ, R., Kâ, S., Thiaw, O. T., De Morais, L. T., Le Loc'h, F., Rozuel-Chartier, E., Auger, D., \& Chiffoleau, J. F. (2013). Assess-ment of trace metal contamination in mangrove ecosystems from Senegal. West Africa Chemosphere, 90(2), 150-157

Chai, M., Li, R., Tam, N. F. Y., et al. (2019). Effects of mangrove plant species on accumulation of heavy metals in sediment in a heavily polluted mangrove swamp in Pearl 
River Estuary, China. Environmental Geochemistry and Health, 41, 175-189

Constance, A., Paul, J., Haverkamp, Bunbury N., SchaepmanStrub, G., (2021) Extent change of protected mangrove forest and its relation to wave power exposure on Aldabra Atoll. Global Ecology and Conservation, (p. e01564), ISSN 2351-9894

Cusack, M., Arrieta, J. M., \& Duarte, C. M. (2020). Source Apportionment and elemental composition of atmospheric total suspended particulates (TSP) over the red sea coast of Saudi Arabia. Earth System and Environment, 4, 777-788

El-Said, G. F., \& Youssef, D. H. (2013). Ecotoxicological impact assessment of some heavy metals and their distribution in some frac-tions of mangrove sediments from Red Sea, Egypt. Environmental Monitoring Assessment, 185(1), 393-404. https://doi.org/10.1007/s10661-0122561-9

FAO (Food and Agriculture Organization of the United Nations). (2007). The world's mangroves 1980-2005. FAO Forestry Paper 153. (p. 77). Food and Agricultural Organization.

Fernández-Cadena, J. C., Andrade, S., Silva-Coello, C. L., \& De la Igle-sia, R. (2014). Heavy metal concentration in mangrove surface sediments from the north-west coast of South America. Marine Pollution Bulletin, 82(1), 221-226. https://doi.org/10.1016/j.mar-polbul.2014.03.016

Hamed, M. A., \& Emara, A. M. (2006). Marine molluscs as biomonitors for heavy metal levels in the Gulf of Suez, Red Sea. Journal of Marine Systems, 60(2006), 220-234

He, B., Li, R., Chai, M., \& Qiu, G. (2014). Threat of heavy metal contamination in eight mangrove plants from the Futian mangrove forest, China. Environmental Geochemistry and Health, 36, 467-476

Imaz-Lamadrid, M. A., Wurl, J., \& Ramos-Velázquez, E. (2019). Future of coastal lagoons in arid zones under climate change and anthropogenic pressure. A case study from San Jose Lagoon, Mexico. Resources. https://doi.org/ 10.3390/resources 8010057

Kinuthia, G. K., Ngure, V., Beti, D., Lugalia, R., Wangila, A., \& Kamau, L. (2020). Levels of heavy metals in wastewater and soil samples from open drainage channels in Nairobi, Kenya: Community health implication. Scientific Reports. https://doi.org/10.1038/s41598-020-65359-5

Kopp, J. F., Korner, R. C., (1967) Trace elements in waters of the United States. Ohio: U.S. Department of Interior, F.W.P.C.A., Division of pollution surveillance

Kumar, V., Parihar, R. D., Sharma, A., Bakshi, P., Sidhu, G. P., Bali, A. S., Karaouzas, I., Bhardwaj, R., Thukral, A. K., Gyasi-Agyei, Y., Rodrigo-Comino, J. (2019). Global evaluation of heavy metal content in surface water bodies: A meta-analysis using heavy metal pollution indices and multivariate statistical analyses. Chemosphere, 236, 124364. https://doi.org/10.1016/j.chemosphere.2019. 124364.

Leite, R. A., Nóbrega, G. N., Leal, L. R. Z. C., et al. (2021). The colonization of a coastal lagoon by a mangrove ecosystem: Benefit or threat to the lagoon? Aquatic Botany, 171, 103362

Li, R., Chai, M., \& Qiu, G. Y. (2016). Distribution, fraction, and ecological assessment of heavy metals in sediment-plant system in mangrove forest South China Sea. PLoS ONE. https://doi.org/10.1371/journal.pone.0147308

Long, C., Dai, Z., Xhou, X., Mei, X., \& Van, C. (2021). Mapping mangrove forests in the Red River Delta, Vietnam. Forest Ecology and Management, 483, 118910. https://doi.org/10. 1016/j.foreco.2020.118910.

MacFarlane, G. R., Pulkownik, A., \& Burchett, M. D. (2003). Accumulation and distribution of heavy metals in the grey mangrove, Avicennia marina (Forsk.) Vierh.: Biological indication potential. Environmental Pollution, 123(1), 139-151. https://doi.org/10.1016/S0269-7491(02)00342-1

Martínez-López, S., Martínez-Sánchez, M. J., Gómez-Martínez, M. C., \& Perez-Sirvent, C. (2020). Assessment of the risk associated with mining-derived arsenic inputs in a lagoon system. Environmental Geochemistry and Health, 42, 2439-2450

MEPA/IUCN (1987). Saudi Arabia assessment of coastal zone management requirements. Jeddah, Saudi Arabia: Meteorology and environmental protection, vol 7.

Morcos, S. A. (1970). Physical and chemical oceanography of the Red Sea. In M. Barnes (Ed.), Oceanography and Marine Biology. (Vol. 8, pp. 73-202). George Allen and Unwin Ltd.

Rasul, N. M. A. (2015b). Lagoon sediments of the Eastern Red Sea: distribution processes, pathways and patterns. In N. M. A. Rasul \& I. C. F. Stewart (Eds.), The formation, morphology, oceanography and environment of a young ocean basin. (pp. 281-316). Springer.

Rasul, N. M. A., (2015) Lagoon sediments of the Eastern Red Sea: Distribution processes, pathways and patterns. In: Rasul N, Stewart I (Ed.) The Red Sea. Springer Earth System Sciences, Springer, Berlin, Heidelberg.

Shaheen, S. M., \& Tsadilas, C. (2009). Concentration of lead in soils and some vegetable plants in north Nile Delta as affected by soil type and irrigation water. Communication in Soil Science and Plant Analyses, 40, 289-306.

Shaheen, S. M., El-Naggar, A., Antoniadis, V., Moghanm, F. S., Zhang, Z., Tsang, D. C. W., et al. (2020). Release of toxic elements in fishpond sediments under dynamic redox conditions: Assessing the potential environmental risk for a safe management of fisheries systems and degraded waterlogged sediments. Journal of Environmental Management, 255, 109778. https://doi.org/10.1016/j.jenvman. 2019.109778.

Shaheen, S. M., Rinklebe, J., Frohne, T., White, J. R., \& DeLaune, R. D. (2014). Biogeochemical factors governing cobalt, nickel, selenium, and vanadium dynamics in periodically flooded Egyptian North Nile Delta rice soils. Soil Science Society of America Journal, 78, 1065.

Shaheen, S. M., Tsadilas, C. D., \& Rinklebe, J. (2013). A review of the distribution coefficient of trace elements in soils: Influence of sorption system, element characteristics, and soil colloidal properties. Advances in Colloid and Interface Science, 201-202, 43-56.

Sultan, S. A. R., \& Ahmad, F. (1990). Flushing of a coastal lagoon in the red sea. Estuarine, Coastal and Shelf Science, $31,345-349$

USEPA (2002). National recommended water quality criteria. Office of water, Office of science and technology. EPA822-R-02-047. 
USEPA (2009) Drinking water standards and health advisories. Office of Water, Washington, DC, USA. EPA 822-R-09011.

Usman, A. R., Alkredaa, R. S., \& Al-Wabel, M. I. (2013). Heavy metal contamination in sediments and mangroves from the coast of Red Sea: Avicennia marina as potential metal bioaccumulator. Ecotoxicology and Environmental Safety, 97, 263-270

Wang, X., Cui, L., Li, J., Zhang, C., Gao, X., Fan, B., \& Liu, Z. (2021). Water quality criteria for the protection of human health of 15 toxic metals and their human risk in surface water, China. Environmental Pollution, 276, 116628. https://doi.org/10.1016/j.envpol.2021.116628.
WHO. (2011). Guidelines for drinking water quality. (4th ed.). World Health Organization WHO Press.

WHO (2017) Guidelines for drinking-water quality. In 4th (Ed.): Incorporating the first addendum, Geneva.

World Bank and International Finance Corporation (IFC) (2008) World bank group: Environmental, health and safety guidelines for thermal power plants. http://www.ifc.org/ ifcext/enviro.nsf/content/environmentalguidlines.

Publisher's Note Springer Nature remains neutral with regard to jurisdictional claims in published maps and institutional affiliations. 